\title{
The Relationship of TV News Channels Consumption with Political Participation, Political Knowledge and Civic Engagement
}

\author{
Sehrish Mushtaq ${ }^{1} \&$ Fawad Baig $^{2}$ \\ ${ }^{1}$ Forman Christian College (A Chartered University), Lahore, Pakistan \\ ${ }^{2}$ Pakistan Television (PTV), Lahore Centre, Pakistan \\ Correspondence: Sehrish Mushtaq, Forman Christian College (A Chartered University), Department of Mass \\ Communication, Lahore, Pakistan. Tel: 92-323-416-3268. E-mail: mushtaqsehrish@yahoo.com
}

\author{
Received: September 30, 2014 Accepted: January 12, $2014 \quad$ Online Published: April 30, 2015 \\ doi:10.5539/ass.v11n12p46 \\ URL: http://dx.doi.org/10.5539/ass.v11n12p46
}

\begin{abstract}
Pakistani TV news channels have greater viewership than any entertainment channel which shows the political interest of Pakistani citizenry. This study deals with the consumption of TV news channels and its effects on the political participation, political knowledge and civic engagement of youth. Data collected from respondents $(\mathrm{N}=246)$ of six different universities in two urban cities Islamabad and Lahore, showed that social connectedness and civic engagement of youth influenced the political participation while political knowledge was not affected. TV news channels consumption exhibited positive correlation with the political participation, political knowledge and civic participation as well as likelihood to cast vote. Though, this study did not trace the cause and effect relationship of TV news channels consumption with political participation, political knowledge and civic engagement.
\end{abstract}

Keywords: political participation, political knowledge, civic engagement, mass media consumption

\section{Introduction}

In the present age, importance and influence of mass media is undeniable. Mass communication researchers have always been indulged in studying the effects of mass media (Katz, 2001). This media effect paradigm has been shifting from direct and powerful effects to minimal effects and then again settling to significant effect (Katz, 1980; Chaffee \& Hochheimer, 1982; Bryant \& Thompson, 2002; Keppinger, 2008). Effect paradigm furthers this notion that media influence significantly on attitudes, behaviors, perceptions, knowledge and opinions of public. Mass media shape not only social but political behaviors of masses also. Particularly for seeking information, media is reckoned a source by all and sundry, a considerable amount of research has traced newspapers and TV channels both as source of political information (Robinson \& Levy, 1996; Guo \& Moy, 1998). People take information from media, its content shape their opinion and ultimately they may make informed political decisions.

There is a vast body of literature about the role of TV channels on the political participation and engagement of citizenry. Both political scientists and mass communication researchers have studied political participation, engagement and knowledge. Besides a lot of research in this regard no study seems to be conclusive about their relationship with media. As every study has described and operationalised them differently. While defining political participation and civic engagement, some of the researchers were more concerned about engagement and participation rather than its nature of being political or civic (Ekman \& Amna, 2012). In some instances civic engagement was used as a construct including everything from voting in elections to charity, or from bowling in leagues to participate in political rallies and marches (Berger, 2009). Putnam (1993) also included almost everything even he added media consumption in this construct as well. Adler and Goggin (2005) distinguished different types of engagement and discussed political aspect of engagement separately as political participation. They included political knowledge also as a measure of engagement. Some researchers have used only voting as a measure of political participation (Peer, Malthouse, \& Clader, 2003), while some have used intent to vote with other indices like interpersonal discussions and campaign participation (Moy, Xenos, \& Hess, 2005). Civic engagement, political participation and engagement are found to be related with each other (Verba, Scholzman, \& Brady, 1995). 
It is the finding of many authors that watching TV news enhances the political participation, knowledge, civic engagement, political efficacy and trust in political system (Norris, 1996, 2000a, 2000b; Shah, McLeod, \& Yoon, 2001; Zhang \& Chia, 2006; Ho et al., 2011; Kim, Scheufele, \& Han, 2011).Vote casting is considered as embodiment of democratic political process and it is found directly associated with watching news regularly (Paterson, 2000). Some researchers have concluded differently, that TV is the reason for erosion of information levels among viewer. Not everyone tends to grab information from TV channels, as some people switch to entertaining content for the purpose of seeking fun thus causing the declining voter turnout (Gentzkow, 2006).

Different researchers have cited different reason for this negative role of TV and seemed to be in consensus about the mistrust, dissatisfaction, and disengagement from political process among TV viewers (Ansolabehere \& Iyengar, 1995; Capella \& Jamieson, 1997; De Vreese \& Semetko, 2002; Pedersen, 2012). Putnam (2000) has also concluded that high consumption of TV channels has resulted in low level of civic engagement as people indulge in the viewership and are left with no time to socialize. But de Vreese and Boomgaarden (2006) noted "virtuous" media effect of news TV channels rather than "vicious" effects. Curren et al. (2014) also acknowledge that research in the field of political communication is divided between positive and negative effects of media. "Media malaise" (Robinson, 1976) and mobilization role of media (Newton, 1999) both are undeniable. This study will evaluate the role played by media for reinforcing democracy and will measure the relationship of TV news channels' viewership with political participation, knowledge and civic engagement of youth in Pakistan.

Young people are attracted to modern forms of media like TV Talk shows, TV news magazine shows, cable TV, and TV is very important source of information for them (Katz, 1993; Hoffman \& Thomson, 2009). Focus on youth for studying media effect can be accounted for the reason that in this age effects can be stronger than the adult audiences who have already mature perception and notions (Arnett, 1995). People who are reported to be active in their early age, they remain same in the later years also (Jennings \& Stoker, 2004).

Pakistan is a country of 196,174,380 people (Central Intelligence Agency, 2014), 67.1 percent of this population is below the age of 30 and TV channels became main source of information for them during the elections of 2008 and 2013 (Yusaf, 2013). 66 percent Pakistanis believe that TV talk shows provide credible information (Gallup Pakistan, 2013) and youth is satisfied with amount of coverage given to important issues by political talk shows (Mashud et al., 2013). In this scenario and in the light of already done studies, this study will focus on the effects either "virtuous" or vicious" of TV News channel consumption on the political participation, civic engagement and political knowledge.

Our hypotheses for the study are as follows.

H1: TV news channel consumption has a significant association with civic engagement, political knowledge and political participation.

As political participation, knowledge and civic engagement are reported to be related to each other so our next hypothesis predicts relationship between these three also.

H2: Political participation, knowledge and civic engagement have significant relationship with each other.

As in many studies it is found that TV channels viewership somehow influence the social and political activities, it is not clear yet whether people both politically and socially active take much interest in TV channels and other sort of media or watching TV channels and using different media ultimately result in political and civic participation. So lastly it is hypothesized that (H3) increase in TV news channels consumption will cause high level of political participation among youth.

\section{Methods}

The above mentioned hypotheses are tested using data collected through survey as method, which was conducted in Lahore and Islamabad. The questionnaire (see Appendix A) carried questions about the media consumption of youth, their preferences for different forms of media, and their political and social attitudes. A total of 246 respondents (age, $\mathrm{M}=23, \mathrm{SD}=4.16$ and female $51.6 \%$ ) from six different universities of both cities filled the questionnaire. In terms of gender distribution, this data was representative of overall population of Pakistan.

\subsection{Variables and Scale Development}

\subsubsection{Media Consumption}

Questionnaire included detailed measure of media consumption among youth. They were specifically asked to report time, they spent reading newspapers (less than one hour per week $60.2 \%, \mathrm{M}=1.86, \mathrm{SD}=1.27$ ), political magazines (less than one hour per week $80.5 \%, \mathrm{M}=1.39, \mathrm{SD}=0.931$ ), watching TV news (approximately one 
hour per day $29.3 \%, \mathrm{M}=3.1, \mathrm{SD}=1.57$ ) and TV talk shows (less than one hour per week $29.7 \%, \mathrm{M}=2.79, \mathrm{SD}$ $=1.58$ ), listening radio (less than one hour per week $81.7 \%, \mathrm{M}=1.37, \mathrm{SD}=0.985$ ) and using internet (less than one hour per week $31.3 \%, \mathrm{M}=2.85, \mathrm{SD}=1.75$ ), for getting political information. Options in this question ranged from less than one hour per week, 1-3 hours per week, 3-5 hours per week, approximately one hour per day, 2-3 hours per day and 3 or more hours per day. On additive index three different variables are created from these options. Total media consumption is the numeric variable which is made up with the additive index of all types of media consumption with highest 36 and lowest 6 of the value. TV news consumption (highest 12 and lowest 6 value) was made up of TV news and TV talk shows' viewership. While with the additive index of newspaper and political magazine readership generated variable print media consumption (highest 12 and lowest 6 value). While respondents report their media consumption patterns, recalling the exact number of hours they spend using media may be difficult at times.

\subsubsection{Political Participation}

This was the dependent variable in the study and we wanted to see how news and political talk shows on TV channels and attitudes of youth and their activities in society affect their level of political participation. In this study we have used the typology developed by Verba and Nie (1972) for political participation but has modified it according to the situation in Pakistan.

For the measurement of political participation, six different questions were asked $(\alpha=0.757)$. These questions addressed different activities and options ranged from never, rarely, once or twice in a week to always. Activities included participation in student societies (rarely $46.3 \%, \mathrm{M}=2.13, \mathrm{SD}=0.854$ ), discussion of politics with friends, family and colleagues (daily $34.1 \%, \mathrm{M}=2.97, \mathrm{SD}=0.927$ ), sharing political content on social media like Facebook and Twitter (rarely $30.9 \%, \mathrm{M}=2.35, \mathrm{SD}=1.03$ ), writing letter about any political issue to TV anchors or politicians (never $78.5 \%, \mathrm{M}=1.28, \mathrm{SD}=0.591$ ), participation in any political rally (never $48.4 \%, \mathrm{M}$ $=1.63, \mathrm{SD}=0.710)$ and likelihood to cast vote in any election $(\mathrm{M}=2.60, \mathrm{SD}=0.630)$. While for voting three options yes $(67.5 \%)$, no $(24.8 \%)$ and not sure $(7.7 \%)$ were listed. A numeric variable of political participation was created after computing the values of six questions regarding political participation. This variable carried the lowest value 6 and the highest value 35 .

\subsubsection{Civic Engagement}

In this study we have derived this construct from the definition of Ekman and Amna (2012). Level of activity and participation in community was also measured with six questions $(\alpha=0.69)$. Questions were asked about the sports activity (rarely $45.9 \%, \mathrm{M}=2.54, \mathrm{SD}=0.874$ ), religious activity (rarely $36.2 \%, \mathrm{M}=2.82, \mathrm{SD}=0.923$ ), donations respondents give (once or twice a week $44.7 \%, \mathrm{M}=2.55, \mathrm{SD}=0.697$ ), volunteer work (rarely $53.7 \%$, $\mathrm{M}=2.05, \mathrm{SD}=0.773$ ) and money for social cause (rarely $54.1 \%, \mathrm{M}=1.84, \mathrm{SD}=0.721$ ) and participation in human rights organization (rarely $49.6 \%, \mathrm{M}=1.81, \mathrm{SD}=0.721$ ). In these questions, options were never, rarely, once or twice in a week and always. A numeric variable of civic engagement was created with the additive index of six questions (lowest value 6, highest 36).

\subsubsection{Political Knowledge}

Political knowledge has been used in some studies as independent variable (Junn, 1991; Carpini \& Keeter, 1996; Milner, 2002; Larcinese, 2005) while in some studies it has been a dependent variable (de Vreese \& Boomgaarden, 2006; Grönlund \& Milner, 2006; Kenski \& Stroud, 2006). But in studies mostly related to political participation or engagement it remained a predictor. So in this study also we will measure its relationship with media consumption pattern and then also see its effect on political participation.

In every study political knowledge seems to be a construct not easy to measure. In some researches self-reporting measure has been used for political knowledge. But this is very subjective way of assessing knowledge as most of the people will rate themselves as knowledgeable persons. Objective measure of political knowledge has also some problems as some people may have better recalling so they can easily give answer to some general political questions (Gojra, 2012).

We followed Adler and Goggin (2005) and asked four general political knowledge questions to measure political knowledge. In these questions every right answer was scored 1 while wrong answer earned 0 . Total political knowledge was calculated after adding the scores of four questions with maximum score 4 and minimum 0 .

\subsubsection{Control Variables}

In this study demographic variables age $(\mathrm{M}=23, \mathrm{SD}=4.16)$, gender $(\mathrm{M}=1.5, \mathrm{SD}=0.501$ and female $51.6 \%)$ and years of education $(\mathrm{M}=2.06, \mathrm{SD}=0.826)$ are included as control variables. 


\section{Results}

Table1 shows a correlation matrix of our control variables, three constructs and TV news channel and print media consumption. Among control variables two were categorical in nature, so for gender and year of education we applied Spearman rank correlation while for rest of variables Pearson's correlation is applied. According to the table gender is correlated negatively to political knowledge $(\mathrm{rho}=-0.323, \mathrm{p}<0.05)$, civic engagement ( $\mathrm{rho}=$ $-0.270, \mathrm{p}<0.05$ ) and political participation (rho $=-0.201, \mathrm{p}<0.05$ ). Age is found correlated to political knowledge $(\mathrm{r}=0.285, \mathrm{p}<0.05)$ and political participation $(\mathrm{r}=-0.155, \mathrm{p}<0.01)$ while years of education is correlated to political knowledge $(r=0.242, \mathrm{p}<0.05)$ only.

TV news channel consumption is positively associated to political participation $(\mathrm{r}=0.202, \mathrm{~N}=246, \mathrm{p}<0.01)$, political knowledge $(r=0.184 . p<0.01)$ and civic engagement $(r=0.148, p<0.05)$. This correlation matrix provides evidence for $\mathrm{H} 1$. Table 1 further shows a significant positive relationship of political participation with civic engagement $(r=0.445, p<0.01)$ while political participation is not associated with political knowledge $(\mathrm{r}=0.057, \mathrm{p}>0.05)$.

Table 1. Relationship of control variables and total media, print media and TV news channels consumption with political participation, political knowledge and civic engagement.

\begin{tabular}{|c|c|c|c|c|}
\hline & & $\begin{array}{c}\text { Political } \\
\text { Knowledge }\end{array}$ & $\begin{array}{c}\text { Political } \\
\text { Participation }\end{array}$ & $\begin{array}{c}\text { Civic } \\
\text { Engagemen } \\
\end{array}$ \\
\hline \multirow{2}{*}{ Gender } & Spearman Correlation & $-.323^{n+\pi}$ & $-.201^{* \pi}$ & $-.270^{\infty \pi}$ \\
\hline & Sig. (2-tailed) & 000 & .002 & 000 \\
\hline \multirow{2}{*}{ Years of Education } & Spearman Correlation & $.242^{* *}$ & -.108 & -.073 \\
\hline & Sig. (2-tailed) & 000 & .092 & .255 \\
\hline \multirow{2}{*}{ Age } & Pearson Correlation & $.285^{* *}$ & $-.155^{*}$ & -.031 \\
\hline & Sig. (2-tailed) & 000 & .015 & .633 \\
\hline \multirow{2}{*}{$\begin{array}{l}\text { TV News Channel } \\
\text { Consumption }\end{array}$} & Pearson Correlation & $.184^{* *}$ & $.202^{-\pi}$ & $.148^{\circ}$ \\
\hline & Sig. (2-tailed) & .004 & .001 & .020 \\
\hline \multirow{2}{*}{$\begin{array}{l}\text { Print Media } \\
\text { Consumption }\end{array}$} & Pearson Correlation & $.162^{\circ}$ & $.281^{n \pi}$ & $.148^{\circ}$ \\
\hline & Sig. (2-tailed) & .011 & .000 & .020 \\
\hline Total Media & Pearson Correlation & $.185^{\circ-}$ & $.332^{* *}$ & $.237^{n+}$ \\
\hline Consumption & Sig. (2-tailed) & .004 & .000 & .000 \\
\hline \multirow{2}{*}{ Political Participation } & Pearson Correlation & .057 & 1 & $.445^{n+}$ \\
\hline & Sig. (2-tailed) & .374 & & .000 \\
\hline \multirow{2}{*}{ Civic Engagement } & Pearson Correlation & -.033 & $.445^{\circ n}$ & 1 \\
\hline & Sig. (2-tailed) & .602 & .000 & \\
\hline \multirow[t]{2}{*}{ Political Knowledge } & Pearson Correlation & 1 & .057 & -.033 \\
\hline & Sig. (2-tailed) & & .374 & .602 \\
\hline
\end{tabular}

**. Correlation is significant at the 0.01 level (2- tailed).

*. Correlation is significant at the 0.05 level (2-tailed).

Correlation matrix shows a significant negative relationship of civic engagement with political knowledge $(\mathrm{r}=$ $-0.033, \mathrm{p}<0.05$ ). In this way our hypothesis $\mathrm{H} 2$ is partially proven as civic engagement and political participation are correlated but political knowledge does not have significant positive relationship with other two.

Table 2. Relationship between TV talk shows and intension of vote casting.

\begin{tabular}{cccc}
\hline & Value & Df & Asymp. Sig. (2-sided) \\
\hline Pearson Chi-Square & $20.146^{\text {a }}$ & 10 & .028 \\
Likelihood Ratio & 22.599 & 10 & .012 \\
Linear-by-Linear Association & 5.460 & 1 & .019 \\
\hline
\end{tabular}

a. 6 cells (33.3\%) have expected count less than 5 . The minimum expected count is 1.00 .

For further elaboration a Pearson chi square test (see Table 2) is performed on the viewership of TV news and TV Talk shows with intention to cast vote in any coming elections. TV news viewership does not show any 
significant relationship but results reveal a significant relationship between viewership of TV talk shows and intension of youth to cast vote (Chi square value $=20.146, \mathrm{df}=10, \mathrm{p}<0.05$ ).

Table 3 shows the matrix of hierarchical regression in which political participation is entered as dependent variable while independent variables are entered stepwise. In the model, years of education and political knowledge are not added because political participation is not found associated with both of these variables in correlation matrix.

In the first step, demographic variables age and gender are entered. In this step, R-square which is the proportion of variation in the dependent variable (political participation) that is explained by demographics is $7.7 \%$. In second step civic engagement is included and R-square is $23.1 \%$ for this model. In the next step, print media consumption is added as independent variable and both TV and print media bring small change in R-square as it reaches to $28.2 \%$ now. The R-square now reaches to $28.7 \%$, it is not a significant change brought in dependent variable on the part of TV news channels consumption but overall model brings a considerable change. While $p$ $<0.001$ at every step of the model explains that the model is fit to measure the relationship and it has accurately measured almost no change in political participation with regard to TV news channel consumption though both are strongly associated.

Table 3. Change in political participation.

\begin{tabular}{|c|c|c|c|c|c|c|c|}
\hline \multirow{2}{*}{$\begin{array}{l}\text { No. } \\
1\end{array}$} & \multicolumn{2}{|c|}{ Model Political Participation ( $\beta$ ) } & \multirow[t]{2}{*}{ Rsquare } & \multirow{2}{*}{$\frac{\mathbf{T}}{14.934}$} & \multirow{2}{*}{$\begin{array}{l}\text { Sig. } \\
.000\end{array}$} & \multirow{2}{*}{$\frac{\mathbf{F}}{10.059}$} & \multirow{2}{*}{$\frac{\text { Sig. }}{.000^{\mathrm{a}}}$} \\
\hline & (Constant) & & & & & & \\
\hline & Age & -.206 & & -3.032 & .003 & & \\
\hline & Gender & -.236 & .076 & -3.711 & .000 & & \\
\hline \multirow[t]{4}{*}{2} & (Constant) & & & 7.080 & .000 & 24.265 & $.000^{\mathrm{b}}$ \\
\hline & Age & -.175 & & -2.806 & .005 & & \\
\hline & Gender & -.124 & & -2.030 & .043 & & \\
\hline & Civic Engagement & .409 & .231 & 6.981 & .000 & & \\
\hline \multirow[t]{5}{*}{3} & (Constant) & & & 6.954 & .000 & 23.643 & $.000^{\mathrm{c}}$ \\
\hline & Age & -.173 & & -3.167 & .002 & & \\
\hline & Gender & -.111 & & -1.955 & .052 & & \\
\hline & Civic Engagement & .377 & & 6.578 & .000 & & \\
\hline & Print Media Consumption & .228 & .282 & 4.120 & .000 & & \\
\hline \multirow[t]{6}{*}{4} & (Constant $)$ & & & 6.761 & 000 & 19.333 & $.000^{\mathrm{d}}$ \\
\hline & Age & -.163 & & -3.089 & .002 & & \\
\hline & Gender & -.114 & & -2.027 & .044 & & \\
\hline & Civic Engagement & .367 & & 6.386 & .000 & & \\
\hline & Print Media Consumption & .206 & & 3.544 & .000 & & \\
\hline & V News Channel Consumption & .079 & .287 & 1.336 & .183 & & \\
\hline
\end{tabular}

a. All requested variables entered. b. Dependent Variable: Political Participation

a. Predictors in the Model: (Constant), Age, Gender

b. Predictors in the Model: (Constant), Age, Gender, Civic Engagement

c. Predictors in the Model: (Constant), Age, Gender, Civic Engagement, Print Media Consumption

d. Predictors in the Model: (Constant), Age, Gender, Civic Engagement, Print Media Consumption, TV News Channel Consumption

Individual beta scores reveal that consumption of TV news channels $(\beta=0.079, p>0.001)$ is not a significant predictor of political participation while print media consumption $(\beta=0.228, \mathrm{p}<0.000)$ and civic engagement $(\beta=0.409, \mathrm{p}<0.001)$ are considerable predictors of dependent variable. In this way our hypothesis $\mathrm{H} 3$ is partially accepted because the percentage of variance explained by the independent variable is not equal to $60 \%$. Besides these variables demographics also do not seem to bring any significant change in political participation. Though, age and gender are found to be associated with three of our constructs. It may be the limitation of data that role of demographics is not detected because samples is from universities of two urban cites, and in universities usually students are of same age group and with very less difference even in socioeconomic status. 


\section{Conclusion}

Though, this study does not indicate, how far TV news channels are playing "virtuous" or vicious" roles while informing public, but it is concluded that youth who is watching TV news channels is somehow involved in political activity also. A positive correlation points out that watching both news and political talk shows more on TV channels will enhance the level of civic engagement and political participation both. It is also proven that people who are socially active with high level of civic engagement, they tend to have high level of political participation also.

As it is the limitation of survey method that collected data may have some inaccuracies on the part of reporting form the respondents. Therefore, it is difficult to analyze from the data, whether people who are active already they are watching TV news channels or after watching TV news channels they become more active. This study did not trace the cause and effect relationship of TV news channels consumption with political participation, political knowledge and civic engagement.

Another important underlying assumption of this study was that educated people watching more and more news channels will also be better informed with higher level of political knowledge. Most of the previous studies looking for the relation of media exposure with political knowledge has found positive correlation between two (Chaffee \& Frank, 1996; Curren et al., 2014; Carpini \& Keeter, 1996; Eveland, 2002; Junn, 1991; McLeod et al., 1999). In our study political knowledge is not correlated to any other construct including media consumption. Dahl (1979) considered the well informed citizens crucial for strengthening democratic tradition. Only people with political knowledge can weigh down the political situation, compare different candidate in electoral process, make informed decisions, and take active part in different activities other than voting. But it seems that in Pakistan without political knowledge people are being active in political activity.

So, TV news channels seem to have some positive effects as there is positive association between civic engagement and political participation. And though negative influence is not confirmed but having played no role towards increase in political knowledge is a shortcoming of TV news channels itself. As TV news channels may bring both kinds of effects on the audience so here the argument developed in a cross national study of 11 countries by Curren et al. (2014) can be reinforced that research on the effects of TV channels must come out of this "binary simplicity" of positive and negative effects as both stances are right in some way.

\section{References}

Adler, R. P., \& Goggin, J. (2005). What do we mean by "civic engagement"? Journal of Transformative Education, 3(3), 236-253.

Ansolabehere, S., \& Iyengar, S. (1995). Going Negative. New York: Free Press.

Arnett, J. (1995). Adolescents' uses of media for self-socialization. Journal of Youth and Adolescence, 24(5), 519-533. http://dx.doi.org/10.1007/BF01537054

Berger, B. (2009). Political theory, political science, and the end of civic engagement. Perspectives on Politics, 7(2), 335-350. http://dx.doi.org/10.1017/S153759270909080X

Bryant, J., \& Thompson, S. (2002). History of the scientific study of media effects. In J. Bryant, \& S. Thompson (Eds.), Fundamentals of media effects (pp. 35-64). Boston: McGraw Hill.

Capella, J., \& Jamieson, K. (1997). Spiral of Cynicism. New York: Oxford University Press.

Carpini, M. X. D., \& Keeter, S. (1996). What Americans Know about Politics and Why It Matters. New Haven, CT: Yale University Press.

Central Intelligence Agency. (2014). The World Factbook. Retrieved from https://www.cia.gov/library/ publications/the-world-factbook/geos/print/country/countrypdf_pk.pdf

Chaffee, S., \& Hochheimer, J. L. (1982). The beginnings of political communications research in the United States: Origins of the "limited effects" model. In E. M. Rogers, \& F. Balle (Eds.), The media revolution in America and in Western Europe (pp. 267-296). Norwood, NJ: Ablex.

Chaffee, S., \& Frank, S. (1996). How Americans get political information: Print versus broadcast news. The Annals of the American Academy of Political and Social Science, 546(1), 48-58. http://dx.doi.org/10.1177/0002716296546001005

Curren, J., Coen, S., Soroka, S., Aalberg, T., Hayashi, K., Hichy, Z., Iyenger, S., ... Tiffin, R. (2014). Reconsidering 'virtuous circle' and 'media malaise' theories of the media: An 11-nation study. Journalism, 15(7), 1-19. http://dx.doi.org/10.1177/1464884913520198 
Dahl, R. A. (1979). Procedural democracy. In P. Laslett, \& J. Fishkin (Eds.), Philosophy, Politics, and Society (pp. 97-133). New Haven: Yale University Press.

De Vreese, C., \& Semetko, H. (2002). Cynical and engaged: Strategic campaign coverage, public opinion, and mobilization in a referendum. Communication Research, 29(6), 615-641. http://dx.doi.org/10.1177/ 009365002237829

De Vreese, C., \& Boomgaarden, H. (2006). News, political knowledge and participation: The differential effects of news media exposure on political knowledge and participation. Acta Politica, 41(4), 317-341. http://dx.doi.org/10.1057/palgrave.ap.5500164

Ekman, J., \& Amna, E. (2012). Political participation and civic engagement: Towards a new typology. Human Affairs, 22(4), 283-300. http://dx.doi.org/10.2478/s13374-012-0024-1

Eveland, W. (2002). News information processing as mediator of the relationship between motivations and political knowledge. Journalism and Mass Communication Quarterly, 79(1), 26-40. http://dx.doi.org/10. $1177 / 107769900207900103$

Gajora, L. (2012). Online Behaviour and Political Knowledge - Effects of Internet Use on Actual and Self-Perceived Political Knowledge, Issue Certainty and Political Participation. Saarbrücken, Germany: LAP Lambert Academic Publishing GmbH \& Co. KG.

Gallup Pakistan. (2013, July 24). 66\% Pakistanis believe that Pakistani political talk shows on TV channels provide credible information; $25 \%$ believe they spread false news. Retrieved from http://www.gallup.com.pk/pollsshow.php?id=2013-07-24

Gentzko, M. (2006). Television and voter turnout. The Quarterly Journal of Economics, 121(3), 931-972. http://dx.doi.org/10.1162/qjec.121.3.931

Grönlund, K., \& Milner, H. (2006). Determinants of political knowledge in comparative perspective. Scandinavian Political Studies, 29(4), 386-406. http://dx.doi.org/10.1111/j.1467-9477.2006.00157.x

Guo, Z., \& Moy, P. (1998). Medium or message? Predicting dimensions of political sophistication. International Journal of Public Opinion Research, 10(1), 25-50. http://dx.doi.org/10.1093/ijpor/10.1.25

Ho, S. S., Binder, A. R., Becker, A. B., Moy, P., Scheufele, D. A., Brossard, D., \& Gunther, A. C. (2011). The role of perceptions of media bias in general and issue-specific political participation. Mass Communication and Society, 14(3), 343-374. http://dx.doi.org/10.1080/15205436.2010.491933

Hoffman, L., \& Thomson, T. (2009). The effect of television viewing on adolescents' civic participation: Political efficacy as a mediating mechanism. Journal of Broadcasting and Electronic Media, 53(1), 3-21. http://dx.doi.org/10.1080/08838150802643415

Jennings, M. K., \& Stoker, L. (2004). Social trust and civic engagement across time and generations. Acta Politica, 39(4), 342-379. http://dx.doi.org/10.1057/palgrave.ap.5500077

Junn, J. (1991). Participation and political knowledge. In W. Crotty (Ed.), Political Participation and American Democracy (pp. 193-212). New York: Greenwood Press.

Katz, E. (1980). On conceptualizing media effects. In T. McCormack (Ed.), Studies in Communications (pp. 119-141). Greenwich, CT: JAI Press.

Katz, J. (1993, November 25). The media's war on kids. Rolling Stone, 130, 47-49.

Katz, E, Blumler, J., \& Gurevitch, M. (1974). Utilization of mass communication by the individual. In J. G. Blumler, \& E. Katz (Eds.), The Uses of Mass Communication: Current Perspectives on Gratifications Research (pp. 19-32). Beverley Hills, CA: Sage Publications.

Kenski, K., \& Stroud, N. J. (2006). Connections between Internet use and political efficacy, knowledge, and participation. Journal of Broadcasting \& Electronic Media, 50(2), 173-192. http://dx.doi.org/10.1207/s 15506878jobem5002_1

Keppinger, H. M. (2008). Media effects. In W. Donsbach (Ed.), The International Encyclopedia of Communication. New York: Wiley-Blackwell

Kim, E., Scheufele, D., \& Han, J. Y. (2011). Structure or predisposition? Exploring the interaction effect of discussion orientation and discussion heterogeneity on political participation. Mass Communication and Society, 14(4), 502-526. http://dx.doi.org/10.1080/15205436.2010.513469

Larcinese, V. (2007). Does political knowledge increase turnout? Evidence from the 1997 British general 
election. Public Choice, 131(3-4), 387-411. http://dx.doi.org/10.1007/s11127-006-9122-0

Mashud, M. N., Chaudhry, I. H., Amin, S., \& Khan S. M. (2013). Television channels' current affairs programs and students' gratification: A case of University of Sargodha. Berkeley Journal of Social Sciences, 3(1), $1-18$.

McLeod, J., Scheufele, D., \& Moy, P. (1999). Community, communication, and participation: The role of mass media and interpersonal discussion in local political participation. Political Communication, 16(3), 315-336. http://dx.doi.org/10.1080/105846099198659

Moy, P., Xenos, M. A., \& Hess, V. K. (2005). Communication and citizenship: Mapping the political effects of infotainment. Mass Communication \& Society, 8(2), 111-131. http://dx.doi.org/10.1207/s15327825mcs 0802_3

Newton, K. (1999). Mass media effects: Mobilization or media malaise? British Journal of Political Science, 29(4), 577-599. http://dx.doi.org/10.1017/S0007123499000289

Paterson, T. (2002). The Vanishing Voter. New York: Vintage Books.

Pedersen, R. T. (2012). The game frame and political efficacy: Beyond the spiral of cynicism. European Journal of Communication, 27(3), 225-240. http://dx.doi.org/10.1177/0267323112454089

Peer, L., Malthouse, E. C., \& Calder, B. J. (2003). Estimating the effect of news media consumption on political participation. Presented at Annual Meeting of American Political Science Association, Philadelphia, PA.

Putnam, R. D. (2000). Bowling Alone: The Collapse and Revival of American Community. New York: Simon \& Schuster.

Putnam, R. D., Leonardi, R., \& Nanetti, R. (1993). Making Democracy Work. Civic Traditions in Modern Italy. Princeton: Princeton University Press.

Robinson, M. J. (1976). Public affairs television and the growth of political malaise: The case of "The Selling of the Pentagon". American Political Science Review, 70(2), 409-432. http://dx.doi.org/10.2307/1959647

Robinson, J. P., \& Levy, M. R. (1996). News media use and the informed public: A 1990s update. Journal of Communication, 46(2), 129-135. http://dx.doi.org/10.1111/j.1460-2466.1996.tb01478.x

Shah, D. V., McLeod, J. M., \& Yoon, S.-H. (2001). Communication, context, and community: An Exploration of print, broadcast, and Internet influences. Communication Research, 28(4), 464-506. http://dx.doi.org/10.1177/009365001028004005

Verba, S., \& Nie, N. H. (1972). Participation in America: Political Democracy and Social Equality. New York: Harper \& Row.

Verba, S., Schlozman, L. K., \& Brady, H. E. (1995). Voice and Equality: Civic Voluntarism in American Politics. Cambridge, MA: Harvard University Press.

Vigna. S. D., \& Ethan K. (2007). The Political Impact of Media Bias. Retrieved from http://elsa.berkeley.edu/ sdellavi/wp/mediabiaswb07-06-25.pdf

Yusuf, H. (2013). Mapping Digital Media: Pakistan. Open Society Foundations: London, UK.

Zhang, W., \& Chia, S. W. (2006). The effects of mass media use and social capital on civic and political participation. Communication Studies, 57(3), 277-297. http://dx.doi.org/10.1080/10510970600666974

\section{Appendix A}

\section{Variables}

\section{Media consumption}

Approximately how much do you use any of the following media as a source to get political information?

a) Newspapers, b) Political Magazines, c) TV News, d) TV Talk Shows, e) Radio News, f) Internet.

[Responses: Less than 1 hour per week (coded: 1), 1-3 hours per week (coded: 2), 3-5 hours per week (coded: 3 ), Approximately 1 hour per day (coded: 4), Approximately 2 to 3 hours per day (coded: 5), 3 or more hours per day (coded 6)]

Please indicate that how often you do the following activities? 
Vote Intent

Civic Engagement

\section{Political Knowledge}

\section{Demographics}

Age

Gender

Year of Education a) Participate in student societies, b) Discuss politics with friends and family, c) Share political content on Facebook/Twitter, d) Write letter to TV channel or TV anchor on political issue, e) Participate in political rally or event.

[Responses: Never (coded: 1), Rarely (coded: 2), Once or twice a week (coded: 3), Daily (coded: 4)]

Will you cast vote for any upcoming local bodies or national level elections?

[Responses: Never (coded: 1), Not sure (coded: 2), Yes (coded: 3)] Please indicate that how often you do the following activities?

a) Play sports, b) Participate in religious activities, c) Donate or collect money for social cause, d) Volunteer for relief work, e) Participate in human right organization.

[Responses: Never (coded: 1), Rarely (coded: 2), Once or twice a week (coded: 3), Daily (coded: 4)]

Select the appropriate answers of the following questions:

a) Which political office is Abid Sher Ali holding?

[Responses: Minister of Defence (coded: 0), Minister of Water \& Power (coded: 1), Minister of Foreign Affairs (coded: 0)]

b) Who is the chief justice of Pakistan?

[Responses: Iftikhar Hussain Chaudary (coded: 0), Umer Ata Bandial (coded: 0), Nasir-ul-Mulk (coded: 1)]

c) On violation of which article is Pervez Musharraf being tried for treason on charges of suspension of constitution?

[Responses: Article 7 (coded: 0), Article 6 (coded: 1), Article 19 (coded: 0)]

d) According to the constitution of Pakistan, which institution is supreme to make laws?

[Responses: Council of Islamic Ideology (coded: 0), Supreme Court (coded: 0), National Assembly (coded: 1)]

What is your age?

What is your gender?

[Responses: Male (coded: 1) or Female (coded: 2)]

Indicate years of education you have completed.

[Responses: 12-14 Years (coded: 1), 14-16 Years (coded: 2), 16-18 Years (coded: 3), Above 18 Years (coded: 4)]

\section{Copyrights}

Copyright for this article is retained by the author(s), with first publication rights granted to the journal.

This is an open-access article distributed under the terms and conditions of the Creative Commons Attribution license (http://creativecommons.org/licenses/by/3.0/). 